\title{
INVESTIGATION ON THE MECHANICAL, THERMAL, BIO-DEGRADATION, AND BIO-COMPATIBILITY PROPERTIES OF POLY (LACTIC ACID) / POLY (ETHYLENE GLYCOL) BLEND
}

\author{
ZOHREH ZARINKOLAH ${ }^{1}$, HAMED BAGHERI ${ }^{*}$, SAMAN HOSSEINKHANI ${ }^{2}$, \\ AND MARYAM NIKKHAH ${ }^{2}$ \\ ${ }^{1}$ Faculty of Interdisciplinary Science and Technology, \\ ${ }^{2}$ Faculty of Biological Sciences, \\ Tarbiat Modares University, Tehran, Iran \\ "Corresponding author: hbagheri@modares.ac.ir
}

(Received: 19 th May 2020; Accepted: $29^{\text {th }}$ July 2020; Published on-line: $4^{\text {th }}$ January 2021)

\begin{abstract}
Absorbable sutures are widely used in surgery. In addition to acceptable mechanical properties, the surgical sutures should exhibit favorable degradability properties. In this research, the mechanical and thermal properties, hydrophilicity, biodegradability, $\mathrm{pH}$ changes, and drug release profile of polylactic acid (PLA) and polyethylene glycol (PEG) alloy were examined to fabricate absorbable sutures. The test results for the mechanical properties showed that the strength of the PLA/PEG alloy decreased with increasing PEG content, leading to an increase in elongation. The differential thermal analysis indicated that the resulting material was above its glass transition temperature (Tg) at ambient temperature and was thus flexible enough. According to the degradation test results, the alloys were degraded similar to the commercial sample. Furthermore, the $\mathrm{pH}$ measurements revealed that the degradation of the alloy had no significant effect on the $\mathrm{pH}$ of the environment. Bupivacaine hydrochloride was incorporated into a certain amount of PLA and PEG, and the drug release rate was then measured. The sample provided a suitable substrate for burst release. Moreover, the cytotoxicity test was carried out to evaluate the biocompatibility properties of the PLA/PEG alloy and it was found that this alloy is biocompatible and the biocompatibility of the material decreases with increasing drug loading.
\end{abstract}

ABSTRAK: Sutur boleh serap telah digunakan dalam pembedahan secara meluas. Tambahan kepada sifat-sifat mekanikal ini, sutur pembedahan perlu memiliki ciri-ciri kebolehurain yang dikehendaki. Dalam kajian ini, sifat-sifat mekanikal dan terma, kehidrofilikan, kebolehuraian, perubahan $\mathrm{pH}$, dan profil penguraian ubat asid polilaktik (PLA) dan aloi polietilena glikol (PEG) telah dikaji bagi mencipta sutur boleh serap. Hasil kajian mendapati sifat-sifat mekanikal menunjukkan kekuatan PLA/PEG aloi berkurangan dengan penambahan level PEG, menyebabkan bertambahnya pemanjangan. Analisis pembezaan terma menunjukkan hasil bahan adalah melepasi suhu perubahan gelas $(\mathrm{Tg})$ pada suhu sekitar dan oleh itu sangat lentur. Berdasarkan hasil kajian degradasi, aloi ini telah digradasi seperti sampel komersial. Tambahan lagi, ukuran $\mathrm{pH}$ menunjukkan degradasi aloi ini tidak menunjukkan kesan langsung pada $\mathrm{pH}$ persekitaran. Bupivacaine hidroklorida dimasukkan ke dalam PLA dan PEG, dan kadar ubat dibebaskan kemudiannya diukur. Sampel substrat yang bersesuian disediakan bagi pelepas letus. Tambahan, ujian Kesitotoksikan telah dijalankan bagi menilai ciri-ciri keserasian-bio aloi PLA/PEG dan didapati aloi ini serasi-bio dan keserasian-bio bahan berkurangan dengan penambahan beban ubat. 
KEYWORDS: surgical suture; drug release; PLA / PEG; bupivacaine hydrochloride; blend

\section{INTRODUCTION}

Surgical sutures are one of the most common types of biomaterials. Natural or synthetic sutures are used to ligate blood vessels or to hold tissues together [1][2]; hence, they can potentially be suitable for the delivery of a pain reliever in the surgical site to reduce the patient's drug dose and potential side effects. A wide range of biopolymers have been used in various medical applications, including drug delivery. Currently, most studies in this field focus on modern controlled drug delivery systems [3].

Sutures have been used as a platforms for the release of antimicrobial drugs such as triclosan-coated sutures [4], which, due to drug resistance, were replaced with silver nanoparticles such as silver solution-soaked multifilament absorbable PLGA sutures [5][6]. To release analgesics such as ibuprofen, the drug was loaded on PLGA sheets and was physically connected to commercially available Vicryl sutures [7]. Natural compounds such as plant extracts, which are rich in phenolic compounds, have received much attention in wound healing applications [5].

A new material with desirable properties can be produced by blending various polymers. A wide range of properties can be obtained using this method to reach a specific goal in a relatively short period at a lower cost, compared to polymerization processes [8][9]. The properties of such systems can be improved using appropriate chemical and physical compatibility techniques as well as methods reducing tensile space in the molten state and increasing phase dispersion and adhesion [10]. In this study, drug-loaded sutures were prepared by mechanical blending of polylactic acid (PLA) and polyethylene glycol (PEG) with bupivacaine $\mathrm{HCl}$ as a strong local anesthetic drug having a long-lasting effect [11].

Given that mechanical blending is a simple, cost-effective, and large-scale production method, and PLA is much cheaper than polymers used in the surgical suture industry, the desired properties can be achieved by combining PLA with other polymers. This composition has not yet been used for surgical sutures. The drug loaded on the resulting material is another novelty of the present study.

\section{MATERIALS AND METHODS}

\subsection{Materials}

Polylactic acid (PLA) was purchased from Hisun PLA---REVODE190 (L130); polyethylene glycol (PEG) with Mw (6000) was purchased from Merck Company; Bupivacaine hydrochloride was also purchased from Aburaihan Pharmaceutical Co Ltd. Synthetic absorbable sutures (MONOCRYL®) were kindly donated from ETICON.

\subsection{Preparation of Blends}

Four samples were prepared by blending a mixture of two polymers PLA / PEG with $5,10,15,20 \mathrm{wt} . \%$ PEG and $60 \mathrm{~g}$ weight $\{12-14]$. The material was dried in an oven at 35 ${ }^{\circ} \mathrm{C}$ for 10 hours. Each sample was homogeneous as a result of mixing in an internal mixer manufactured by Brabender Germany Model W50 at $180{ }^{\circ} \mathrm{C}$ and $80 \mathrm{rpm}$ for a 15 -minute duration. For mechanical and biological tests, the samples were prepared in sheets with 1$\mathrm{mm}$ diameter by hot press machine made by Toyo seiki model $\mathrm{WCH}(2002)$ at $190{ }^{\circ} \mathrm{C}$ and pressure of $50 \mathrm{kPa}$ for 5 minutes. The sample was then pressurized to $27 \mathrm{kPa}$ for 5 minutes by cold press. 


\subsection{Preparation of Drug-containing Samples}

Solvent casting sampling was performed on the PLA/PEG sample with $15 \mathrm{wt} \%$ PEG and bupivacaine hydrochloride with 5,10 , and $15 \mathrm{wt} \%$ of the drug. The polymer mixture was dissolved in dichloromethane at $10 \mathrm{wt} . \%$. Then the weight concentrations of the drug were added to $10 \mathrm{wt} \%$ PLA/PEG polymer mixture [15]. The homogeneous solution was poured into a mold. After 72 hours, the solvent evaporation and the sample containing the drug were prepared.

\subsection{Mechanical Testing}

Prototyping was performed according to ASTM D882 with length, width, and thickness of 110,20 , and $1 \mathrm{~mm}$, respectively. The test was performed by GT7010-D2E, manufactured by GOTECH Taiwan, at a speed of $5 \mathrm{~mm} / \mathrm{min}$, with a $50 \mathrm{~mm}$ interval between the jaws. The test was performed on 4 samples with 5, 10, 15, and $20 \mathrm{wt} \%$ PEG and 3 specimens were taken to determine data point.

\subsection{Thermal Analysis}

To carry out this test in accordance with ISO 11357, the DSC $200 \mathrm{~F} 3$, manufactured by NETZSCH, was set up at a temperature of $25^{\circ} \mathrm{C}$ to $220^{\circ} \mathrm{C}$ and a rate of $5{ }^{\circ} \mathrm{C} / \mathrm{min}$.

\subsection{Biodegradability Test}

To perform this test in accordance with ISO 13781, the samples were prepared in strips of approximately $10 \times 20 \times 5 \mathrm{~mm}$ and placed in $50 \mathrm{ml}$ of PBS buffer with a $\mathrm{pH}$ of about 7.4 at $37^{\circ} \mathrm{C}$.

The weight loss of the sample was examined over seven months at two-week intervals. At the specified time intervals, the samples were extracted from the buffer solution, washed twice with distilled water, and incubated at a temperature of $45^{\circ} \mathrm{C}$ for 5 hours. They were then dried and weighed by scales.

\subsection{Measuring pH Changes}

The samples were prepared as $10 \times 20 \times 5 \mathrm{~mm}$ strips and placed in $50 \mathrm{ml}$ of phosphate buffer saline (PBS) at $\mathrm{pH} 7.4$ and $37{ }^{\circ} \mathrm{C}$. The $\mathrm{pH}$ changes in the solution containing the samples were performed at a time interval of 7 months and two-week intervals. At the end of the experiment, the $\mathrm{pH}$ value was measured by $\mathrm{pH}$ meter device (made by Sana model SANA SL-901), and then, was replaced with freshly-made PBS solution every time.

\subsection{Contact Angle Test}

The contact angle was measured with a drop of water ( $4 \mu \mathrm{l})$ using a system equipped with a drop-shot CCD camera and a drop-angle contact angle measurement software at the desired level.

\subsection{In-vitro Release Study}

To measure the release rate, $10 \mathrm{mg}$ of PLA/PEG polymeric sample containing $15 \mathrm{wt} \%$ PEG and bupivacaine hydrochloride with 5, 10, and $15 \mathrm{wt} \%$ were prepared and dissolved in $50 \mathrm{ml}$ of phosphate buffered saline (PBS) with a $\mathrm{pH}$ of approximately 7.4 at $37{ }^{\circ} \mathrm{C}$ by incubator shakers LIEBHERR models manufactured by Tintometer Germany at $180 \mathrm{rpm}$. After $0,0.5,1,4,8$, and 24 hours for 14 days, $2 \mathrm{ml}$ of the extract was daily replaced with $2 \mathrm{ml}$ of PBS buffer. The extract absorption rate was measured by using uv spectroscopy manufactured by Biochrom U.K. Model WPA to determine the concentration of the drug. 


\subsection{Cytotoxicity Test}

The MTT cytotoxicity test method examined the samples containing drug to measure cell viability in the presence of various concentrations of the drug. The test was performed on the MEF (CF-1) and HEK-293 cell lines (donated by Tarbiat Modarres University).

\section{RESULTS AND DISCUSSION}

\subsection{Tensile test}

As shown in Fig. 1, the stress is reduced in the samples containing 5, 10, 15, and 20 wt $\%$ PEG. A comparison between the PLA/PEG and pure PLA strain rates in Fig. 2 shows that the strain is significantly influenced by increased PEG level due to a decrease in PLA level. This finding is reasonable since the PLA/PEG melt is expected to have interstitial properties.

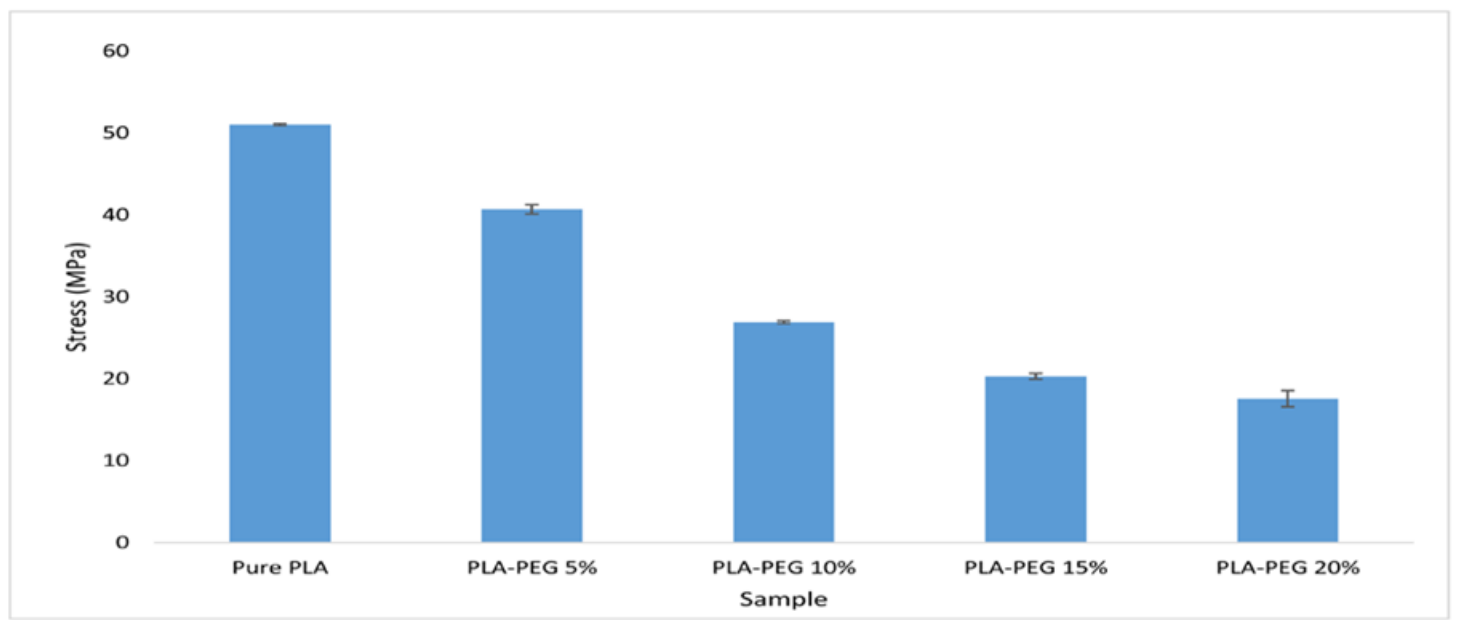

Fig. 1: Tensile strength properties as a function of increasing (\%) PEG.

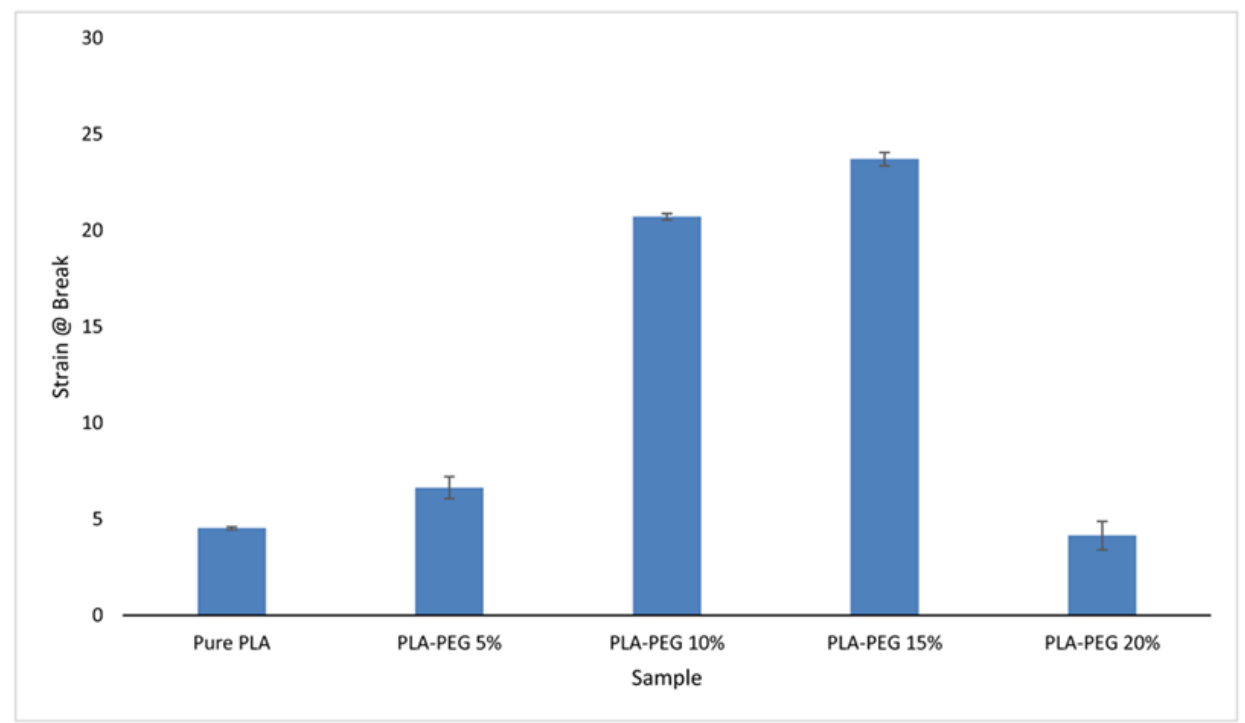

Fig. 2: Elongation properties as a function of increasing (\%) PEG.

The stress and strain rates in PLA/PEG20\% were not similar to the ones observed for the other samples such that the strain rate decreased with an increase in the PEG level. 
According to Pillin et al. two substances are miscible to a certain extent under blending conditions. Therefore, the observed behavior can be caused by the immiscibility of PLA and PEG in this composition [16].

In this study, blending process aimed at obtaining a composition with desirable properties to fabricate absorbable sutures; therefore, the final blend should have a proper strain to better control and handle the resulting sutures. On the other hand, strength is a significant factor in the preparation of sutures with desirable properties [1,17]. The main point was to find a composition with the maximum elongation against the lowest strength reduction. According to the results of the tensile test and considering the abovementioned criterion, the PLA/PEG sample with $15 \mathrm{wt} \%$ PEG had the lowest strength reduction with maximum elongation.

\subsection{Differential Thermal Analysis}

Figure 3 shows the differential thermal analysis curve for five samples. As it can be observed, the peaks in the diagram represent the phase changes of the material.

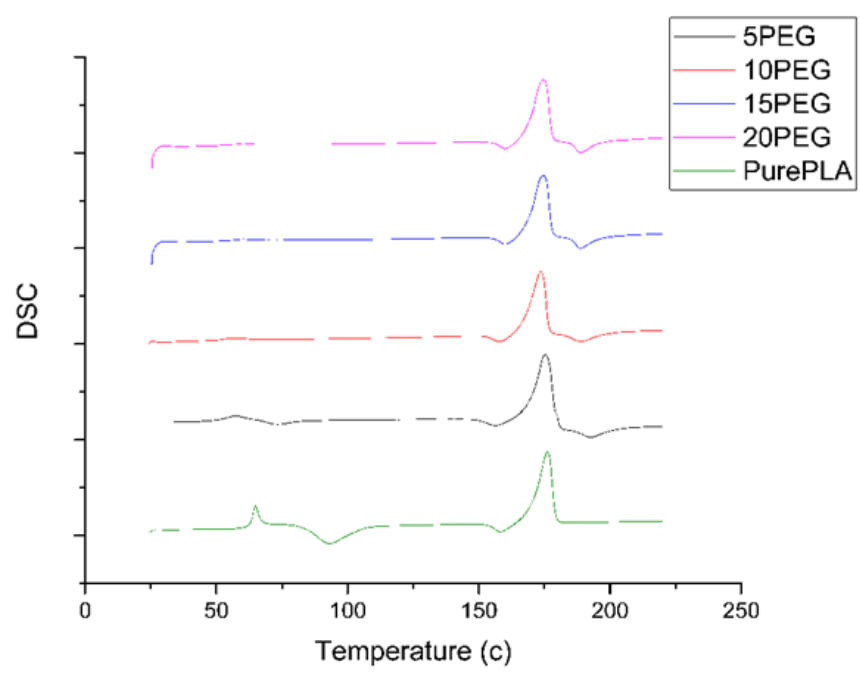

Fig. 3: DSC curves of PLA / PEG samples.

According to Table 1, the amount of the absorbed heat decreased with an increase in the PEG level. Given that the glass transition temperature (Tg) of PEG is $63{ }^{\circ} \mathrm{C}$ [18], the less heat absorbed for the phase change was due to an increase in the PEG level. On the other hand, PLA and PEG are miscible, and the glass transition temperature of the polymeric alloy is expected to be decreased with the increase in the PEG level. Considering the low glass transition temperature of PEG, the reduction in $\mathrm{Tg}$ of the alloy is reasonable and indicates the plasticizing effect of PEG as a plasticizer. The decrease in the Tg peak reveals that the resulting material is softened at ambient temperature. The plasticizing effect of PEG is also proven in the tensile test. On the other hand, the peak $T_{m}$ has also decreased due to the decrease in the PLA level, and also by calculating the area under the curve of this peak (Table1), it proves that the volume of heat received in the whole material has decreased.

Table 1: Thermal properties of PLA-PEG blends derived from DSC curve

\begin{tabular}{cccccc}
\hline sample & Pure PLA & $\begin{array}{c}\text { PLA/PEG } \\
\mathbf{5 \%}\end{array}$ & $\begin{array}{c}\text { PLA/PEG } \\
\mathbf{1 0 \%}\end{array}$ & $\begin{array}{c}\text { PLA/PEG } \\
\mathbf{1 5 \%}\end{array}$ & $\begin{array}{c}\text { PLA/PEG } \\
\mathbf{2 0} \%\end{array}$ \\
\hline$\Delta \mathrm{H}(\mathrm{J} / \mathrm{g})$ & 7.936 & 6.306 & 5.796 & 5.435 & 4.121 \\
\hline
\end{tabular}




\subsection{Degradation Test}

Figure 4 presents the rate of weight loss for all the samples. All samples experienced a weight loss, compared to pure PLA so that the weight loss increased with an increase in the PEG level. A comparison of the graphs revealed that the degradability properties of PLA were improved as a result of it being mixed with PEG. The degradability rate of the commercially available MONOCRYL Poliglecaprone 25 sutures was also measured for further comparison. In this regard, pure PLA revealed no weight loss within 36 weeks, and this might be due to the crystalline structure of PLA [19]. The PLA/PEG sample containing $15 \mathrm{wt} \%$ PEG showed a weight loss close to that of the commercial sutures. However, the weight loss of the commercial sutures was measured during a 4-week period, although there was no possibility to measure the weight because of the appearance of the sample. Given the semi-crystalline structure of PLA, the penetration of buffer or any other liquid into PLA mass is difficult [19].

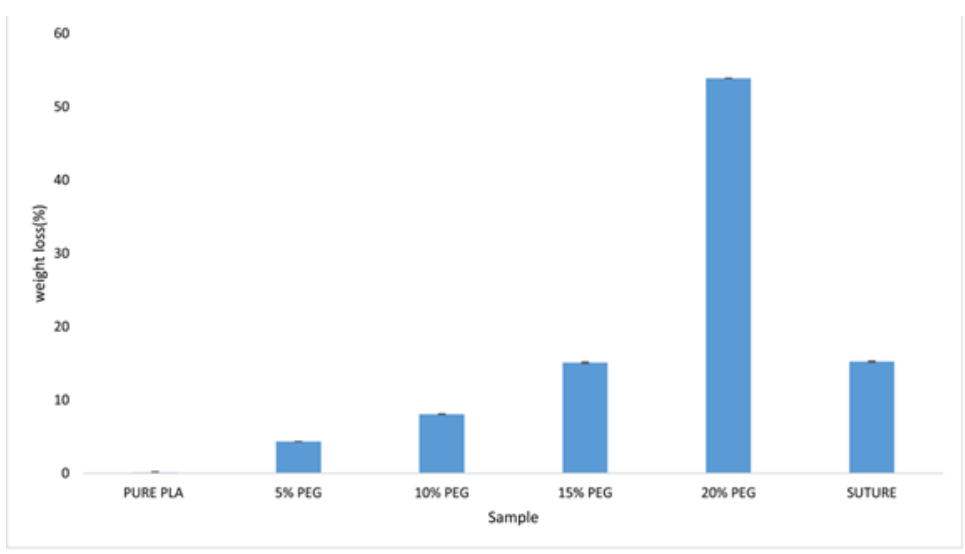

Fig. 4: Loss of mass of the of PLA / PEG specimens as a function of (\%) PEG.

With the increase in the amount of PEG added to PLA, the buffer penetration into the polymeric mass improved due to the nature of PEG. This led to the failure of the polymeric backbone, and the weak points in the material then caused cracking. Given that wound healing requires a reduction in the strength of sutures and the gradual removal of sutures, the failure at the surface would reduce strength and eventually facilitate the removal of sutures. The micrographs of the degradation test are shown in Fig. 5.

\section{4 pH Changes}

Figure 6 presents $\mathrm{pH}$ changes during the degradation of the PLA/PEG samples. Accordingly, the $\mathrm{pH}$ measured to the initial $\mathrm{pH}$ increased maximum 3 to $4 \%$. Given that the $\mathrm{pH}$ of the body is about 7.4, and the maximum change was 0.2 units, the prepared samples did not change the $\mathrm{pH}$ in the body.

\subsection{Contact Angle Test}

Table 2 lists the contact angle of a water droplet on the surface of pure PLA and PLA/PEG blends containing 5, 10, 15 and $20 \mathrm{wt} \%$ PEG. A smaller contact angle indicates a more hydrophilic nature of the material. In this study, the contact angle decreased with increasing PEG in the resulting blend, implying the effect of hydrophilic properties of PEG. 

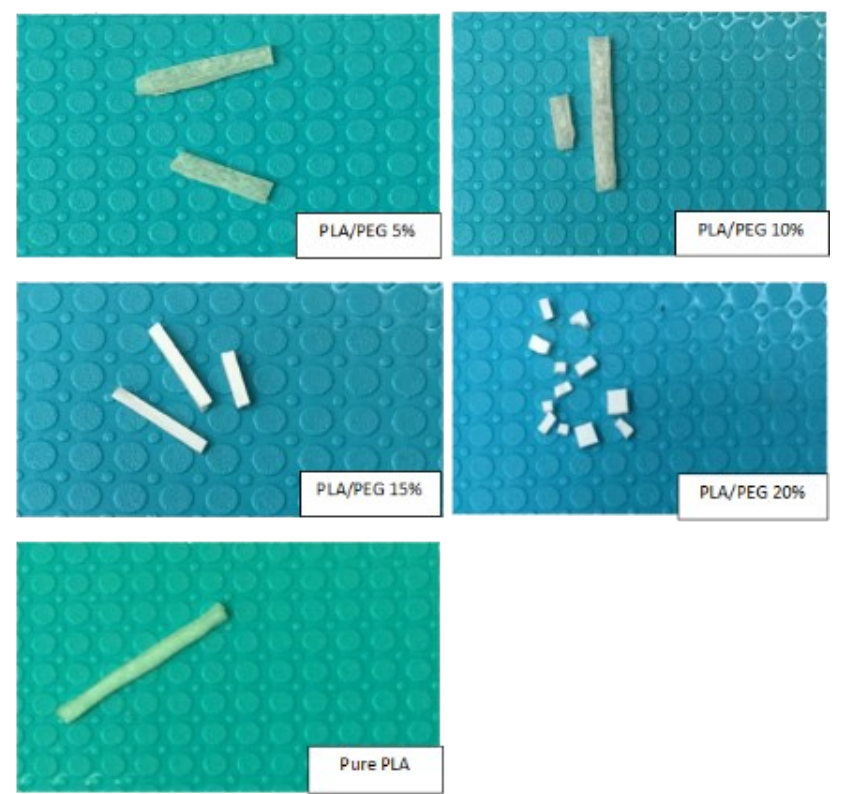

Fig. 5: Micrograph of samples after 34th week of degradation test.

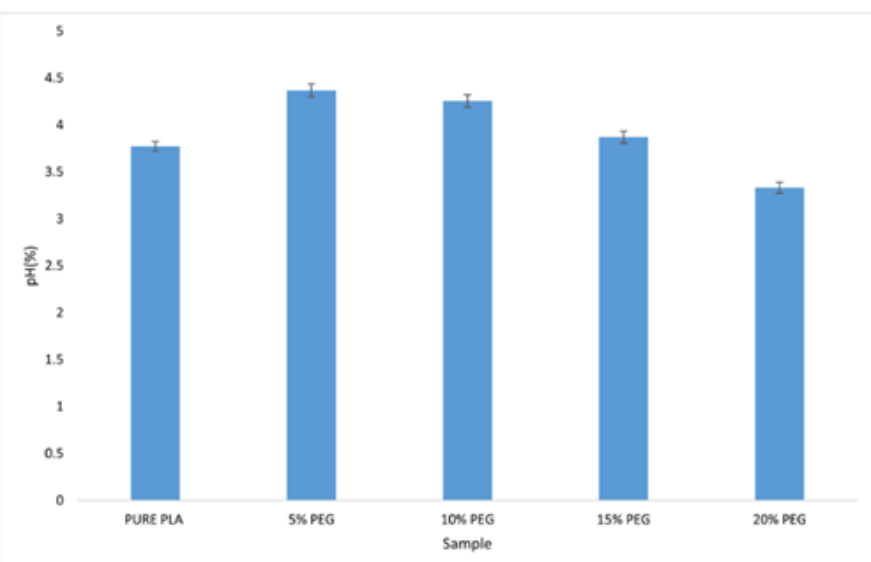

Fig. 6: Variations in $\mathrm{pH}$ of the degradation media as a function of (\%) PEG.

Table 2: Water Contact angle measurement on surface of PLA / PEG samples

\begin{tabular}{cccccc}
\hline sample & Pure PLA & $\begin{array}{c}\text { PLA/PEG } \\
\mathbf{5 \%}\end{array}$ & $\begin{array}{c}\text { PLA/PEG } \\
\mathbf{1 0} \%\end{array}$ & $\begin{array}{c}\text { PLA/PEG } \\
\mathbf{1 5 \%}\end{array}$ & $\begin{array}{c}\text { PLA/PEG } \\
\mathbf{2 0} \%\end{array}$ \\
\hline (Degree) contact angle & \multirow{2}{*}{62} & 57 & 46 & 30 & 21 \\
\hline
\end{tabular}

This in turn affected the properties of the blend so that the resulting material became more hydrophilic. Since the absorbable sutures should be hydrophilic to be effectively degraded, the resulting blend was thus suitable for the desired application. As a result, PLA properties were modified in this way. The effect of PEG hydrophilic nature was also observed in the degradation test. The micrograph of the contact angle of the samples is shown in Fig. 7. 


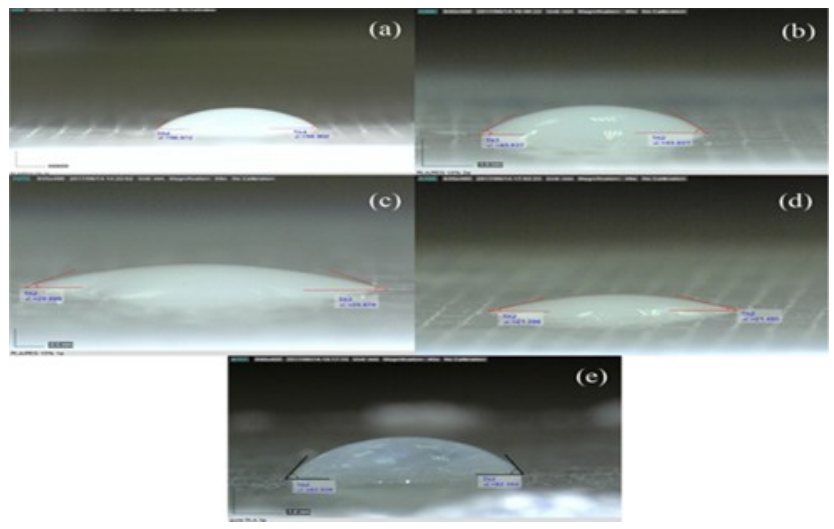

Fig. 7: Water contact angle image of PLA/PEG samples, (a) PLA/PEG 5\%, (b) PLA/PEG 10\%, (c) PLA/PEG 15\%, (d) PLA/PEG 20\%, (e) PLA.

\subsection{Drug Release Profile}

Figure 8 shows the drug release profiles for 312 hours (13 days). The highest drug release rate occurred during 1-4 $\mathrm{h}$ and then a declining trend was observed. In other words, the sample provides a suitable substrate for rapid drug release in the wound site. Since this study aimed at achieving sutures with desired properties for rapid drug release in the first hours of injury at the closure site of a trauma or a scar, all the three samples can be used for this purpose. The concentration of the released drug was increased with an increase in drug loading. This means that the prepared material would be a suitable substrate for the controlled drug release at a required rate.

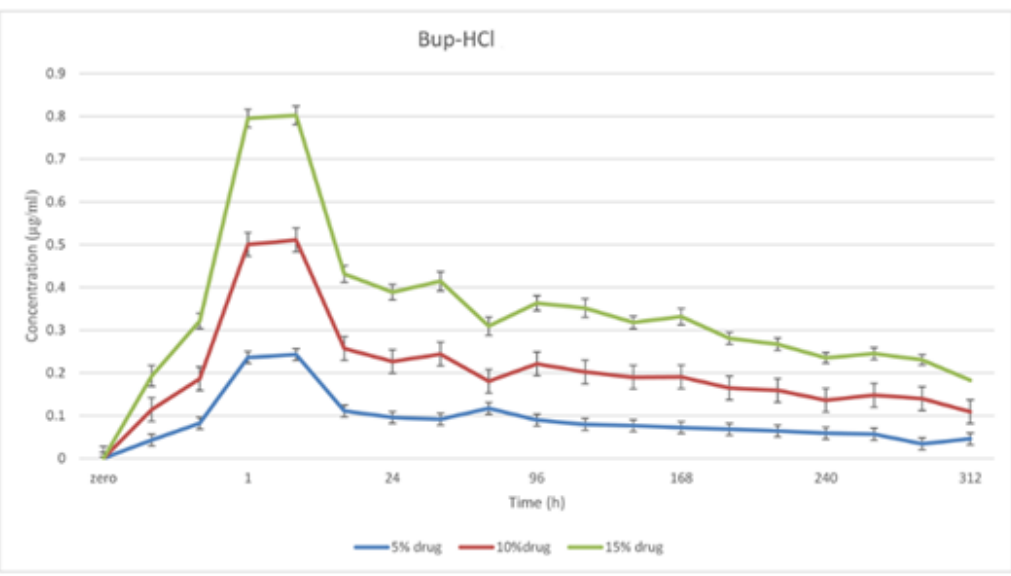

Fig. 8: Modeled in vivo release profiles of bupivacaine hydrochloride of PLA/PEG samples.

\subsection{Cytotoxicity Test}

Figure 9 shows the viability of MEF (CF-1) cell line in the control sample and in the extract containing bupivacaine hydrochloride. As it can be observed, the viability decreased with an increase in the drug percentage [20,21]. Figure 10 shows the viability of HEK-293 cell line in the bupivacaine hydrochloride extract. In this test, the viability of cells decreased with an increase in the drug concentration, as compared to the control sample [20,21]. 


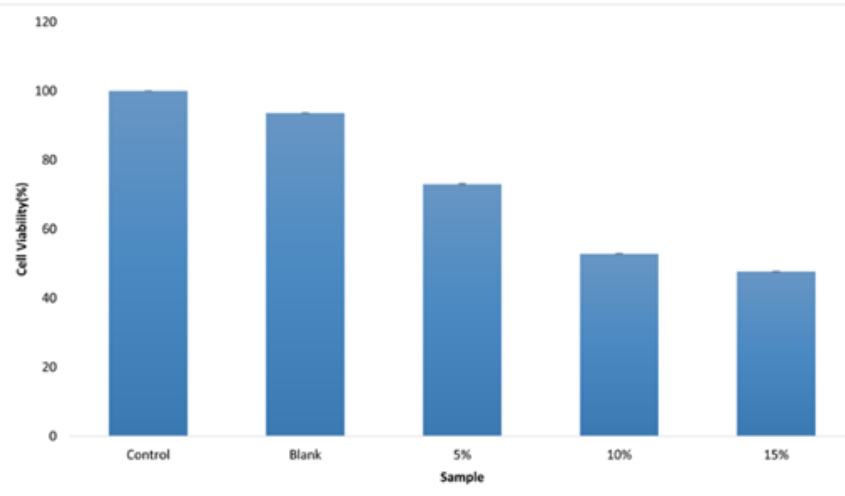

Fig. 9: Percentage of cell viability on the series of the diluted extracted solution of (MEF (CF-1)) in 24 hours in the vicinity of the samples containing drug.

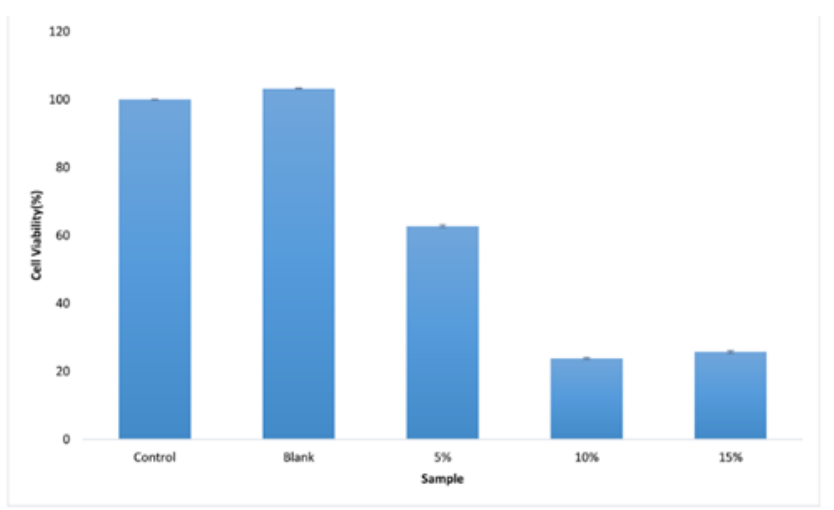

Fig. 10: Percentage of cell viability on the series of the diluted extracted solution of (HEK-293 in 24 hours in the vicinity of the samples containing drug.

According to the results of this study as well as statistical calculations, the difference in cell viability percentage is significant and in the vicinity of the cell with the material extract, has led to cell death. As can be seen in Fig. 9 and Fig. 10, the rate of cell death increased with increasing percentage of drug loaded in the polymer alloy. In the two types of cell lines used, the survival rate of cells is different, which is due to the difference in tolerance of different cell lines. Thus, the HEK-293 cell line had a lower drug tolerance compared to the cell line (MEF (CF-1)).

\section{CONCLUSION}

Polylactic acid (PLA) and polyethylene glycol (PEG) were mechanically blended to obtain interstitial properties. Polylactic acid is a rigid brittle polymer with a high mechanical strength. PLA is rigid at ambient temperature and is almost hydrophobic. Polyethylene glycol is a hydrophilic polymer with a low melting point and high degradation rate. These two polymeric materials are miscible, whose blending results in interstitial properties. The resulting polymeric material is flexible and more hydrophilic than the polylactic acid and exhibits a higher strength than polyethylene glycol. According to the tensile test results, increasing the PEG level caused a decrease in strength but an increase in elongation. In this study, blending aimed at obtaining a composition with desirable properties to produce absorbable sutures. Accordingly, the final blend should have a proper strain for better control and mobility of the resulting sutures. On the other hand, strength is a critical factor in the preparation of sutures with desirable properties. The main point is to find a 
composition with the maximum elongation against the lowest strength reduction. According to the results of the tensile test and considering the abovementioned criterion, PLA/PEG sample with $15 \mathrm{wt} \%$ PEG had the lowest strength reduction with maximum elongation.

The results of the degradation test indicated that increasing the PEG level led to greater penetration of fluids in the polymeric mass, resulting in an increase in the degradation rate. In this study, a PLA/PEG sample containing $15 \mathrm{wt} \%$ PEG showed a weight loss close to that of commercial sutures. It is worth mentioning that the difference in the weights of samples was not significant during the study period, and the material was degraded with no significant weight loss.

According to the contact angle test results, the hydrophilic properties of the resulting polymeric material increased with an increase in the PEG level. Due to the fact that absorbable sutures should be hydrophilic to be effectively degraded, the resulting material would be suitable for the desired application. As a result, PLA properties were modified in this way.

The drug release profiles revealed that the maximum drug release occurred during 1-4 $\mathrm{h}$, and then a declining trend was observed. With an increase in drug loading, the drug concentration also increased, suggesting that the polymeric material would be a suitable substrate for controlled drug release at a required rate.

According to the results of cytotoxicity test on the drug-containing samples, the cell death rate increased with an increase in the amount of drug loaded in the polymeric blend. The cell viability was different in two types of cell lines due to the differences in the tolerance of the cell lines.

\section{REFERENCES}

[1] Pillai CKS, Sharma CP. (2010) Absorbable polymeric surgical sutures: Chemistry, production, properties, biodegradability, and performance. Journal of Biomaterials Applications. 25(4): 291-366. http://jba.sagepub.com/content/25/4/291

[2] Tajirian AL, Goldberg DJ. (2010) A review of sutures and other skin closure materials. Journal of Cosmetic Laser Therapy, 12(6): 296-302. https://doi.org/10.3109/14764172.2010.538413

[3] Ratner BD, Hoffman AS, Schoen FJ, Lemons JE. (1997) Biomaterials Science, An Introduction to Materials in Medicine Book (3rd Edition) 2013. Edited by Ratner BD, Hoffman AS, Schoen FJ, Lemons JE.

[4] Joseph B, George A, Gopi S, Kalarikkal N, Thomas S. (2017) Polymer sutures for simultaneous wound healing and drug delivery - A review," International Journal of Pharmaceutics, 524(1): 454-466, https://doi.org/10.1016/j.ijpharm.2017.03.041

[5] Gallo AL, Paladini F, Romano A, Verri T, Quattrini A, Sannino A, Pollini M. (2016) Efficacy of silver coated surgical sutures on bacterial contamination, cellular response and wound healing. Materials Science and Engineering, C69: 884-893. https://doi.org/10.1016/j.msec.2016.07.074

[6] Hu W, Huang ZM, Liu XY. (2010) Development of braided drug-loaded nanofiber sutures. Nanotechnology, 21(31): 315104 (11pp)

[7] Lee JE, Park S, Park M, Kim MH, Park CG, Lee S.H, Choi SY, Kim BH, Park HJ, Park JH, Heo CY, Choy YB. (2013) Surgical suture assembled with polymeric drug-delivery sheet for sustained, local pain relief. Acta Biomaterialia, 9(9): 8318-8327. https://doi.org/10.1016/j.actbio.2013.06.003

[8] Yu L, Dean K, Li L. (2006) Polymer blends and composites from renewable resources. Progress Polymer Science, 31: 576-602. https://doi.org/10.1016/j.progpolymsci.2006.03.002

[9] Lai W, Liau W, Lin T. (2004) The effect of end groups of PEG on the crystallization behaviors of binary crystalline polymer blends PEG / PLLA. Polymer, 45: 3073-3080. 
[10] Pracella M. (2017) Blends and Alloys. Modification of properties, Elsevier Inc. 155-184

[11] Terry D. (1990) Analytical Profiles of Drug Substances Wilson Sterling Research \& Group Rensselaer, 19: 59-94

[12] Mohapatra AK, Mohanty S, Nayak SK. (2013) Effect of PEG on PLA / PEG Blend and Its Nanocomposites: A Study of Thermo-Mechanical and Morphological Characterization. https://doi.org/10.1002/pc.22660

[13] Ozdemir E, Hacaloglu J. (2017) Characterizations of PLA-PEG Blends Involving Organically Modified Montmorillonite. Journal of Analytical and Applied Pyrolysis 127: 343-349.

[14] Bramfeldt H, Sarazin P, Vermette P. (2008) Blends as a strategy towards tailored hydrolytic degradation of poly ( $\varepsilon$-caprolactone-co-D,L-lactide)-poly(ethylene glycol)-poly( $\varepsilon$ caprolactone-co-D,L-lactide) co-polymers. Polymer Degradation and Stability, 93(4): 877882.

[15] Weldon CB, Tsui JH, Shankarappa SA, Nguyen VT, Ma M, Anderson DG, Kohane DS. (2012) Electrospun drug-eluting sutures for local anesthesia. Journal of Controlled Release, 161(3): 903-909, https://doi.org/10.1016/j.jconrel.2012.05.021

[16] Pillin I, Montrelay N, Grohens Y. (2006) Thermo-mechanical characterization of plasticized PLA: Is the miscibility the only significant factor? Polymer, 47: 4676-4682.

[17] Patel KA, Thomas WEG. (2008) Sutures, ligatures and staples. Surgery 26(2): 48-53.

[18] Wang X, Michael A, Van Den Mooter G. (2004) Study of the phase behavior of polyethylene glycol 6000 - itraconazole solid dispersions using DSC. International Journal of Pharmaceutics (272): 181-187.

[19] Davachi SM, Kaffashi B, Torabinejad B, Zamanian A. (2016) In-vitro investigation and hydrolytic degradation of antibacterial nanocomposites based on PLLA / triclosan / nanohydroxyapatite. Polymer, 83:101-110. https://doi.org/10.1016/j.polymer.2015.12.015

[20] Wang D, Vo NV, Sowa GA, Hartman RA, Ngo K, choe SR, Witt WT, Dong Q, Lee JY, Niedernhofer LJ, Kang JD. (2011) Bupivacaine decreases cell viability and matrix protein synthesis in an intervertebral disc organ model system. The Spine Journal, 11(2): 139-146, https://doi.org/10.1016/j.spinee.2010.11.017

[21] Quero L, Klawitter M, Nerlich AG, Leonardi M, Boos N, Wuertz K. (2011) Bupivacaine-the deadly friend of intervertebral disc cells? The Spine Journal, 11(1): 46-53. https://doi.org/10.1016/j.spinee.2010.11.001 